\title{
Tata Ruang Etnis Dan Profesi Dalam Kota Batavia (Abad XVII - XVIII)
}

\author{
Aryandini Novita; M. Irfan Mahmud
}

Keywords: urban archaeology, jakarta, old city, pattern, spatial distribution

\section{How to Cite:}

Novita, A., \& Mahmud, M. I. (1999). Tata Ruang Etnis Dan Profesi Dalam Kota Batavia (Abad XVII - XVIII). Berkala Arkeologi, 19(2), 77-94. https://doi.org/10.30883/jba.v19i2.824

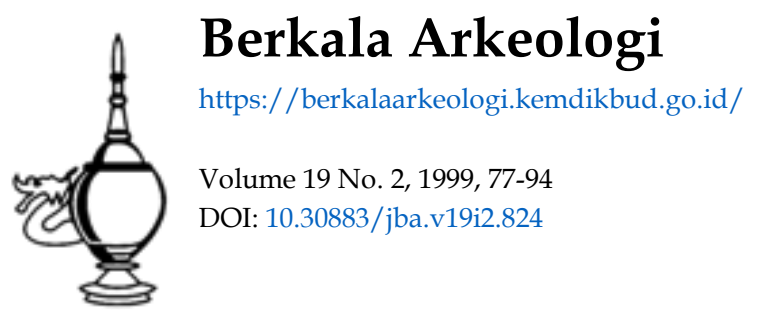

\section{cc) (7) (2)}

This work is licensed under a Creative Commons Attribution-NonCommercial-ShareAlike $\underline{4.0 \text { International License. }}$ 


\title{
TATA RUANG ETNIS DAN PROFESI \\ DALAM KOTA BATAVIA (ABAD XVII - XVIII)
}

\author{
Aryandini Novita \\ M. Irfan Mahmud
}

\section{Pendahuluan}

Sejak jatuhnya Jayakarta ke tangan VOC (1619), wilayah ini tumbuh menjadi kota pelabuhan yang dirancang dengan konsep moderen (Eropa), dan diberi nama Batavia. Lalu, penguasa VOC secara bertahap membangun kota Batavia dengan lay-out mengikuti model Eropa yang berbenteng. Ciri kota Batavia yang menonjol meniru kota Amsterdam abad pertengahan, di mana kota dikelilingi kanal-kanal dan tembok kota (Soekmono, 1992/1993).

Sumber sejarah dan diperkuat dengan peta kolonial, memperlihatkan adanya pengelompokan etnis dalam tata ruang kota Batavia. Sampai sekarang nama-nama etnis masih menjadi monumen nomologis kota Jakarta. Seperti, Kampung Ambon, Kampung Bugis, Pecinan dan sebagainya.

Kelihatannya, ada hubungan antara kelompok etnis, profesi, dan wilayah pemukimannya. Meskipun demikian, dalam pembahasan beberapa penulis belum ada gambaran yang memberi penjelasan tentang ketiga hubungan tersebut. Pada hal, pilihan ruang pemukiman diyakini tidak terbentuk seadanya. Karenanya pertimbangan yang imanen di dalam kesadaran kelompok etnis, baik secara sosiologis, antropologis, maupun politik perlu dilacak.

Sekurang-kurangnya ada tiga soal yang akan dikembangkan dalam tulisan ini. Pertama, faktor-faktor signifikan apa saja yang mempengaruhi pemilihan ruang pemukiman kelompok etnis? Kedua, bagaimana hubungan antara ruang etnis dan profesi? Ketiga, apakah kelompok etnis di luar tembok kota Batavia dapat dianggap kelompok pinggiran?

Persoalan-persoalan di atas diajukan berdasarkan gejala bahwa masyarakat kota Batavia merupakan kesatuan organik yang terdeferensiasi. Di kota Batavia, setiap kelompok masyarakat tinggal di suatu tempat menurut asal-usulnya dan dipimpin oleh orang dari kelompoknya sendiri (Rahardjo, 1991). Keadaan ini disebabkan perdagangan yang menjadi urat nadi perekonomian menjadi magnet bagi pedagangpedagang dari "mancanegara" untuk datang. Selain pedagang, orang-orang yang tinggal di Batavia berprofesi sebagai pegawai VOC, serdadu bayaran, dan pekerja perkebunan. Di samping itu orang-orang yang datang ke Batavia ada juga yang 
merupakan tawanan perang dan budak. Data sejarah menyebutkan bahwa pada abad ke-17 dan 18 penduduk Batavia adalah orang Eropa, Cina, Moor, Jepang, Papanger, Melayu, Ambon, Banda, Buton, Makassar, Bugis, Timor, Mandar, Sumbawa, Bali, dan Jawa. Selain itu, terdapat juga orang-orang keturunan yang merupakan hasil perkawinan orang Eropa yang datang ke Batavia dengan wanita Indonesia atau Asia lainnya yang disebut mestizo. Di samping golongan mestizo terdapat juga orang-orang mardijker, yaitu budak-budak yang didatangkan dari pos-pos dagang VOC di wilayah Asia, tawanan-tawanan perang yang dibawa oleh kapal-kapal VOC atau orang-orang merdeka yang didatangkan ketika Belanda menaklukkan Malaka (de Haan, 1922; Novita, 1995).

Kehadiran kelompok masyarakat tersebut di atas dalam proses perkembangan kota sekurang-kurangnya memperlihatkan tiga gejala yang sering menjadi pusat perhatian peneliti perkotaan. Pertama, pemekaran kota-kota. Kedua, perpindahan penduduk desa ke kota. Ketiga, perubahan suasana desa (rural sphare) menjadi suasana kota (urban sphare). Perubahan suasana desa menjadi suasana kota menimbulkan pandangan pusat-pinggiran (center-periphery). Konsep pusat-pinggiran menurut teori "dualisme" seperti yang diajukan oleh John Friedman (1966) membagi kota menjadi: pusat yang dinamis dan daerah pinggiran yang statis. Selanjutnya ia mengusulkan adanya empat wilayah (region) berdasarkan fungsinya: (1) Core-regions, yang merupakan konsentrasi ekonomi kota dengan memiliki kapasitas inovasi dan perubahan-perubahan tinggi. Wilayah pusat ini memiliki hirarki jaringan ke desa. (2) Upward-transition region adalah daerah tepi dari pusat. Wilayah ini mengandung sumber yang dapat dikembangkan. (3) Resource-frontier regions merupakan daerahdaerah tepi yang digunakan untuk pemukiman baru. (4) Downward-transition regions adalah daerah-daerah yang mengalami stagnasi atau daerah-daerah yang mengalami proses kemunduran (Bintarto, 1986).

Seringkali kita melihat perbedaan wilayah pusat-pinggirankota menurut postur ekonomi. Hal ini memang merupakan kecenderungan kota sekuler-kapitalistik, di mana perbedaan kelas sosial-ekonomi dianggap sebagai penentu eksistensi orang bermukim di suatu wilayah. Konsep ini pernah dilontarkan oleh Castell dan Harvey bahwa, "urban areas can be understood only in termof the conflicts between classes which are a direct outcome of the operation of the capitalist mode of production" (Gibert dan Josef Gugler, 1981). Timbulnya konflik sosial dalam skala kapitalisme bagi kota kolonial di Batavia tidak dapat dipandang sebagai akibat an sich gerakan sosial belaka, karena bisa jadi justru postur konflik politik akan menambah penjelasan pemetaan wilayah pemukiman kota-pinggiran.

Berdasarkan konsep di atas dapat diasumsikan bahwa ada kaitan antara profesi dan pilihan permukiman etnis. Etnis yang bermukim di kota Batavia stereotipe dengan profesi tertentu. Meskipun demikian, permukiman pinggiran bukan indikator 
keterbelakangan ekonomi atau tekanan politik. Terbentuknya permukiman di luar tembok kota dapat saja didorong oleh faktor pembangkangan politik, penghindaran atas kebijakan ekonomi, atau bahkan sebagai refleksi ruang pembatasan akses politik terhadap etnis pribumi. Dengan demikian, perkembangan kota Batavia tidak tumbuh sebagai partisipasi semua kelompok, akan tetapi ada kelompok dominan yang menentukan arah perkembangan kota menurut kepentingannya saja.

\section{Wajah Kota Batavia}

Wajah kota Batavia, sebagaimana kecenderungan kota-kota Eropa umumnya dan Belanda khususnya, telah menerapkan sendi-sendi kota moderen. Bila diamati secara detail sangat tampak adanya obsesi besar VOC sehubungan dengan upaya menguasai perdagangan Asia-Eropa (dunia).

Kota Batavia pada saat didirikan oleh VOC direncanakan sebagai pusat perdagangannya di kawasan Asia. Di kota tersebut terdapat juga pusat administrasi dan militer VOC. Selain itu, Batavia juga direncanakan menjadi tempat beristirahat para pedagang VOC, membuat dan memperbaiki kapal, serta menyimpan barangbarang komoditi VOC (Abeyasakere, 1987; Novita, 1995).

Batavia merupakan kota yang didirikan oleh orang Eropa dengan menggunakan konsep yang dipakai di negara asalnya. Sebagai pusat kegiatan VOC di kawasan Asia, maka Batavia dibangun sedemikian rupa menyerupai kota yang ada di Belanda. Karena itu, Batavia juga merupakan kota yang terbesar di antara kota-kota yang menjadi koloni VOC di Asia (Gill, 1994; Novita, 1995).

Berdasarkan keletakannya terhadap Sungai Ciliwung yang membelah kota Batavia, maka kota Batavia dapat dibagi menjadi tiga bagian, yaitu kota bagian timur, kota bagian barat, dan kota bagian depan. Berikut ini uraian mengenai tata kota Batavia berdasarkan pembagian wilayahnya:

\section{A. Kota Bagian Timur (Oosterstad)}

Pada awalnya, pemukiman di Batavia berada di sisi timur Sungai Ciliwung, tepatnya di bagian luar sisi selatan kastil. Pembangunan kota dilaksanakan oleh Gubernur Jenderal Jan Pieterzoen Coen (1619-1623 dan 1627-1629). Pekerjaan pertama yang dilakukan adalah pembuatan kanal-kanal yang digali dari Sungai Ciliwung ke arah timur. Kanal-kanal pertama yang dibuat berturut-turut dari utara ke selatan, yaitu Steenhouwergracht, Groenegracht, dan Leeuwengracht. Ketiga kanal tersebut kemudian dihubungi oleh kanal yang melintang, yang diberi nama Tijgergra. 
Antara pemukiman dengan kastil dibatasi oleh Kasteelgracht dan dihubungkan oleh sebuah jembatan tarik di muka pintu gerbang kastil (landpoort). Tepat di seberang Kasteelgracht terdapat lapangan kastil (Kateelplein). Di lapangan kastil terdapat beberapa bangunan seperti gudang Dispen, gudang artileri (Ijzermagajizn), gudang senjata (arsenaal) dan tempat tiang hukuman. Di sebelah timur lapangan kastil juga terdapat pergudangan, yaitu Graanpakhuizen.

Balai kota terletak di sisi selatan sejajar dengan kastil. Antara balai kota dengan lapangan kastil terdapat sebuah pintu gerbang menuju Prinsestraat. Di muka balai kota terdapat sebuah lapangan terbuka, stadhuisplein. Di sebelah barat stadhuisplein terdapat sebuah pasar terbuka (nieuwemarkt). Selain itu, pasar juga terdapat di sisi selatan Groenegracht, yaitu Oudegroentemarkt dan di antara Groenegracht dan Leeuwengracht, yaitu Moorschenpasar.

Di sebelah selatan stadhuis kemudian dibuat sebuah kanal. Vierdedwarsgracht, yang berhubungan juga dengan Tijgergracht dan berlanjut hingga Sungai Ciliwung. Di sebelah barat balai kota terdapat gereja (Hollandsche Kerk). Bangunan gereja lainnya yang terdapat di kota bagian timur ini adalah Lutherschekerk di sebelah selatan Amsterdamschegracht dan Maleisekerk yang terletak di sisi barat Binnennieuwpoortstraat, namun pada tahun 1650 gereja tersebut sudah tidak ada lagi, sebagai gantinya terdapat Binnenhospitaal. Di antara Hollandsche Kerk dan Binnenhospitaal terdapat dua buah jalan yang sejajar membujur dari barat ke timur, yaitu Kerkstraat dan Hospitaalstraat.

Sejajar dengan Tijgergracht kemudian dibuat kanal Bandaneeschegracht, di mana pada sisi timurnya terdapat pemukiman orang-orang Banda, dan pada sisi baratnya terdapat sekolah (Compagniesschool). Di sebelah selatan Bandaneeschegracht dibuat juga kanal Malabaarschegracht yang pada sisi timurnya terdapat juga pemukiman orang-orang Malabar serta bengkel kerja VOC (Ambachtskwartier). Di antara Malabaarschegracht dan Tijgergracht terdapat jalan yang bernama Kwartierstraat.

Sebagai batas kota sebelah timur dibuat tembok yang pada sisi dalam dan sisi luarnya dibuat kanal Oosterbinnengracht dan Oosterbuitengracht. Di sepanjang tembok kota dibuat juga bastion-bastion sebagai penjagaan. Pada awalnya bastion-bastion tersebut dibuat dari kayu yang berturut-turut dari utara ke selatan, yaitu Friesland, Groningen, Utrecht. Selain itu, terdapat juga bastion terbuat dari batu, yaitu Gelderland dan Holland.

Pada masa selanjutnya bastion-bastion yang terbuat dari kayu tersebut kemudian diganti dengan bastion batu dan diberi nama Amsterdam, Middelburg, Delft, Rotterdam, Hoorn, Enkhuizen, Vianen, Catzenellenbogen, Oranje. Di antara tepi 
Sungai Ciliwung di sebelah utara Vierdedwarsgracht juga didirikan bastion, yang merupakan bastion yang tertua, yaitu bastion Braband.

Dalam perkembangan berikutnya, terlihat adanya penambahan garis pantai di bagian utara Batavia. Untuk itu, dibangun sebuah garis pertahanan dengan sebuah pos penjagaan (sterreschans). Pada bagian tersebut juga terdapat bangunan-bangunan pergudangan untuk menyimpan logistik (arak-spekvleesch-oliepakhuizen).

\section{B. Kota Bagian Barat (Westerstad)}

Pengembangan kota bagian barat mulai dilaksanakan pada tahun 1627 dengan dibuatnya kanal keliling. Tetapi pembangunan kota mulai terlihat pada masa pemerintahan Gubernur Jenderal Jacques Specx (1629-1632). Pada masa ini terjadi perubahan pada bentuk aliran Sungai Ciliwung. Aliran Sungai Ciliwung yang awalnya berliku-liku kemudian diubah dengan meluruskannya. Dibuat juga kanal yang mengarah ke kota bagian barat dari Vierdedwarsgracht hingga kanal keliling bagian barat. Kota dibagi-bagi dalam kotak-kotak kemudian dibatasi dengan tanggul pertahanan.

Penyelesaian kota Batavia secara keseluruhan dilaksanakan pada masa pemerintahan Gubernur Jenderal Anthonie van Diemen (1632-1645) termasuk kota bagian barat. Pada masa ini dilakukan penguatan dinding pertahanan bagian utara yang pada awalnya merupakan tempat pabean kemudian berganti menjadi Huis van den General Ontvang dan akhirnya berubah menjadi bastion Vierkant.

Pembangunan dilakukan dengan membuat kanal Jovaanschegracht dan Chineeschegracht yang membujur dari barat ke timur dan dihubungkan oleh kanal yang melintang, yaitu Moorschegracht. Sejajar dengan Chineeschegracht dibuat kanal Maleischegracht. Kemudian dari Maleischegracht dibuat kanal-kanal yang melintang dari utara-selatan, yaitu Jonkergracht dan Rhinocerosgracht. Kedua kanal tersebut dibelah oleh sebuah jalan yang membujur dari barat ke timur, yaitu Utrechtschestraat.

Selain pembuatan kanal-kanal, didirikan juga bangunan-bangunan yang berfungsi sebagai bangunan umum. Di Rhinocerosgracht bagian utara pada sisi baratnya terdapat sebuah penjara (spinhuis), karena itu terkadang Rhinocerosgracht disebut juga dengan Spinhuisgracht; dan rumah sakit Cina (Chineesche Hospitaal) serta sebuah sekolah Cina (Chineescheschool). Sedangkan di Rhinocerosgracht bagian selatan pada sisi baratnya terdapat sebuah sekolah (Compagniesschool); rumah penampungan orang miskin (Armhuis); dan rumah penampungan anak yatim (Weeshuis). 
Di Utrechtschestraat terdapat gerja Portugis (Potugeesche Binnenkerk). Beberapa pasar juga terdapat di kota bagian barat, seperti sitsenpasar, rijstmarkt, dan vischmarkt di sisi utara Maleisegracht, hoenderspasar di Kali Besar Barat, serta gouwdiefsmarkt di dekat middelpuntbrug.

Pada kota bagian barat juga terdapat tempat-tempat pengerjaan perbaikan kapal-kapal kayu, yaitu compagnieswerf yang merupakan milik VOC, serta Chinesewerf yang merupakan tempat pengerjaan kayu milik orang Cina yang terletak di Ankerstraat. Selain itu, terdapat juga bangunan pergudangan di tempat-tempat pengerjaan kayu tersebut, yaitu kasteelpakhuizen. Pada sisi selatan tembok kota bagian utara terdapat gudang-gudang penyimpanan rempah-rempah westzijdepakhuizen.

Di sebelah utara tembok kota bagian utara pada perkembangan selanjutnya seperti kota bagian timur, di mana terjadi penambahan garis pantai, terdapat pemukiman orang-orang Jawa (Javaschekwartier). Untuk pertahanan terdapat benteng air (waterkasteel) di sebelah utara pantai Batavia, dan di sebelah barat laut pemukiman orang-orang Jawa didirikan benteng Dieren.

Sama seperti tembok keliling kota bagian timur, pada tembok keliling kota bagian barat didirikan pula bastion-bastion dari batu, yang nama Culemborg, Zeeland, Groningen, Everrijsel, Friesland, Utrecht, dan Grimbergen. Dengan begitu dapat dilihat pada tembok keliling kota bagian barat bastion-bastionnya bernama propinsipropinsi di Belanda dan pada tembok keliling kota bagian timur bastion-bastionnya bernama kamar dagang-kamar dagang VOC.

\section{Kota Bagian Depan (Voorstad)}

Kota bagian depan pada kenyataannya terletak di bagian selatan Batavia. Daerah ini terletak di luar tembok keliling tetapi masih merupakan bagian dari kota Batavia. Untuk melindungi kota bagian depan di sebelah timur terdapat kanal keliling (stadgracht) yang merupakan kelanjutan dari kanal bagian timur sebelah luar (Oosterbuitengracht). Sebagai batas di sebelah selatan dan barat adalah Sungai Ciliwung.

Di kota bagian depan juga dibuat kanal, yaitu Tayolingracht. Pada pertemuan kanal keliling dengan Sungai Ciliwung dibuat penjagaan, yaitu bastion Hollandia. Pada bagian selatan kanal keliling juga terdapat pintu gerbang kota (stadslandpoort) dan sebuah jembatan menuju Heerenweg (kemudian menjadi Jacatrasseweg) yang merupakan jalan menuju luar kota Batavia bagian timur. 
Untuk menuju luar kota bagian timur didirikan sebuah jembatan schipbrug dengan pos penjagaan Brussenburch. Dari pos penjagaan tersebut terdapat jalan Buitennieuwpoortstraat yang merupakan kelanjutan dari Binnennieuwpoortstraat. Pada masa-masa awal perkembangan Batavia pada jalan yang membujur antara Buitennieuwpoortstraat dan Tayolingracht, yaitu Koestraat, terdapat sebuah rumah sakit (Compagnieshospitaal). Sejajar dengan Koestraat terdapat juga jalan, yaitu Kalverstraat.

Berdasarkan uraian mengenai tata kota Batavia, maka dapat diketahui pola tata ruang kota tersebut. Terlihat kota Batavia dapat dibagi menjadi empat kawasan. Pertama, kawasan pusat kota. Kedua, kawasan pemukiman. Ketiga, kawasan niaga. Keempat, kawasn militer.

Sebagai kawasan pusat kota, VOC meletakkannya di kota bagian timur dengan batasbatas sebelah utara adalah Leeuwenegracht, sebelah selatan Oosterbuitengracht, sebelah timur Tijgergracht, dan sebelah barat Sungai Ciliwung. Di kawasan pusat kota tersebut terdapat beberapa bangunan, yaitu balai kota sebagai pusat administrasi dan pemerintahan yang terletak di antara Tijgergracht dan Heerestraay; Hollandschekerk sebagai gereja pemerintah (gereja kota) yang terletak di sebelah barat laut balai kota; pasar di halaman depan balai kota (stadhuisplein); serta sebuah rumah sakit milik pemerintah (binnenhospitaal) di sebelah barat daya balai kota.

Seperti yang telah dibahas sebelumnya, terlihat kawasan pemukiman mengalami beberapa kali perkembangan. Pada awalnya kawasan pemukiman hanya di sebelah timur Sungai Ciliwung kemudian berkembang sampai ke sebelah barat Sungai Ciliwung, hingga terlihat kawasan permukiman terbagi di tiga bagian kota, yaitu di kota bagian timur, kota bagian depan, dan kota bagian barat.

Kawasan pemukiman ini dibatasi oleh tembok keliling, kecuali kota bagian depan batas-batas barat dan selanjutnya adalah sungai Ciliwung dan sebelah timurnya adalah kanal yang merupakan kelanjutan dari Oosterbuitengracht. Selain di ketiga bagian kota tersebut, kawasan pemukiman juga terdapat di daerah luar kota. Sebagai batas dari kawasan pemukiman di daerah luar kota tersebut didirikan benteng-benteng kecil yaitu Ancol dan Jacatra di bagian timur; Noordwijk dan Rijswijk di bagian selatan; serta Angke, vijfhoek, dan pos penjagaan Buitenwacht di bagian barat.

Di daerah kawasan pemukiman ini terdapat beberapa bangunan umum, yaitu gereja, rumah sakit, sekolah, tempat penampungan anak yatim, dan tempat penampungan orang miskin. Selain itu, terdapat juga beberapa bangunan niaga berupa pasar dan sebuah bangunan penjara. 
Di bagian utara kota Batavia terlihat diperuntukkan sebagai kawasan niaga, hal ini mengingatbagian tersebut merupakan daerah pantai di mana terdapat pelabuhan Sunda Kelapa. Batas-batas dari kawasan ini adalah sebelah utara tembok keliling kota dan kastil Batavia; sebelah selatan Jaavaanschegracht, Werfstraat, Ankerwerf, dan Amsterdamschegracht; sebelah timur tembok keliling kota; sebelah barat tembok keliling kota. Di kawasan niaga ini terdapat bangunan-bangunan seperti pergudangan, tempat pengerjaan kayu.

Sebagai kawasan militer dari kota Batavia, diletakkan di sebelah utara dari kawasan niaga. Hal ini dapat dilihat dari adanya Kastil Batavia, pagar pertahanan yang dilengkapi oleh benteng kecil (Sterreschans), Waterkasteel di muara Sungai Ciliwung, dan Benteng Dieren di Muara Baru.

Pemilihan lokasi tersebut sebagai kawasan militer dapat dikatakan karena lokasi tersebut berbatasan langsung dengan laut Jawa dan pada kenyataannya VOC lebih menganggap ancaman yang terbesar berasal dari arah laut, yaitu armada para pesaingpesaingnya terutama Inggris. Kenyataan sejarah mencatat bahwa sampai awal abad XVIII, Inggris masih berusaha merebut Batavia dan tahun 1800, 1806, dan 1811 berhasil menghancurkan Pulau Onrust yang pada masa itu merupakan basis terdepan dari pertahanan Batavia (Heuken, 1989).

Pada kenyataannya di daerah pedalaman juga didirikan benteng-benteng pertahanan tetapi keletakannya menyebar di masing-masing permukiman di luar tembok kota. Berdasarkan kenyataan ini, terlihat VOC tidak memilih lokasi tersebut sebagai kawasan militer. Hal ini juga didukung oleh keterangan sejarah bahwa penyerangan terhadap Batavia dari pedalaman hanya terjadi pada masa-masa awal dibangunnya Batavia, yaitu tahun 1628, dan 1629 oleh kerajaan Mataram (Breuning, 1988).

Pada pertengahan abad 17, VOC sudah mulai merencanakan untuk membuat jalan dan menggali kanal di luar kota. Tujuan utama pembuatan kanal-kanal tersebut adalah sebagai sarana transportasi dari dalam ke luar kota atau sebaliknya. Hal ini disebabkan karena semakin sempitnya lahan pertanian di dalam kota akibat bertambahnya jumlah penduduk di dalam kota (Haris, 1991; Sadadi, 1992).

Penggalian kanal-kanal luar kota ini tidak dilakukan oleh VOC sendiri, melainkan orang-orang partikelir. Kanal-kanal tersebut merupakan sarana yang menghubungkan kota dengan daerah perkebunan tebu dan penggalian gula yang didirikan di tepi kanal. Di samping itu, kanal-kanal tersebut merupakan penghubung dari daerah perkotaan dengan pos-pos penjagaan di luar kota (Haris, 1991). Kanal-kanal luar kota tersebut adalah Antjolsevaart yang mengalir ke arah Timur kota; Amanusgracht, Bacherachtsgracht, Groningenvaart dan Mookervaart ke arah barat; dan Molenvliet ke arah selatan (Haris, 1991; Sadadi, 1992). 
Perkembangan wilayah luar tembok kota semakin meningkat pada awal abad 18 yang ditandai dengan banyaknya pejabat-pejabat VOC membeli tanah terutama di sebelah selatan kota untuk dijadikan tempat peristirahatan. Wilayah tersebut dijadikan kebun yang dilengkapi dengan rumah peristirahatan (landhuis). Selain itu, tanah-tanah milik pejabat VOC tersebut juga disewakan kepada orang-orang Cina untuk dijadikan areal perkebunan. Keadaan ini lama kelamaan mengakibatkan munculnya pemukiman penduduk yang berkembang secara pesatyang dengan sendirinya berarti perluasan wilayah kota.

\section{Pertimbangan Pemilihan Ruang Etnis dan Penataan Kota}

Secara umum penduduk Batavia tersegregasi dalam berbagai macam kelompok etnis. Menurut E. Shevky dan Wendell Bell ada tiga variabel untuk menjelaskan struktur wilayah kota. Pertama, status sosial; kedua, segregasi etnis; dan ketiga budaya kota (Evesr, 1982). Segregasi berkaitan dengan pengertia ruang, pengertian sosialekonomi, politis, dan kebudayaan yang dapat dilihat dari aspek keleluasaan tempat tinggal, tingkat monopolisasi etnis atas tempat pemukiman, komposisi etnis, tingkat asimilasi corak kebudayaan (Evesr, 1982). Pada abad XVII-XVIII, perbedaan ras dan agama merupakan patokan yang dipakai oleh VOC dalam penentuan lapisan sosial dan lokasi pemukiman. Berdasarkan hal tersebut terlihat penduduk Batavia pada masa itu terdiri dari lima kelompok besar, yaitu Eropa, Mestizo, Timur Asing, Mardijker, dan Pribumi (Milone, 1975; Haris, 1991; lihat pula lampiran tabel.

Selain Belanda, bangsa Eropa yang menetap di Batavia berasal dari Jerman, Inggris, Perancis, dan Portugis. Umumnya mereka berprofesi sebagai pejabat dan pegawai VOC, serdadu, pengusaha swasta, dan pemuka agama. Data sejarah menunjukkan bahwa orang-orang Eropa tidak menempati lokasi khusus dalam penempatan pemukimannya. Sebagai warga kelas satu, mereka diberi kebebasan untuk tinggal di dalam atau di luar kota (Haris, 1991). Berdasarkan peta, lokasi pemukiman orang Eropa terletak di sepanjang Tijgergracht, Jonkergracht, di sepanjang tembok keliling kota: sedangkan di luar kota umumnya mereka bertempat tinggal di sekitar Poort Roterdam, Nieuwpoort, Utrechtschpoort, dan tepi-tepi jalan yang menuju ke luar kota.

Kelompok yang menduduki kelas dua di Batavia adalah Mestizo. Yang disebut kelompok Mestizo adalah orang-orang yang merupakan peranakan Eropa dan Asia. Profesi yang dimiliki oleh kelompok ini sebagai pegawai VOC, serdadu, dan pengusaha swasta. Pemukiman kelompok Mestizo berlokasi terutama di kota bagian timur dan kota bagian depan sebelah timur.

Kelompok penduduk kelas ketiga di Batavia adalah kelompok Timur Asing. Masyarakat yang termasuk kelompok ini orang-orang Cina, Moor, Jepang, dan 
Papanger. Di antara kelompok etnis yang termasuk dalam kelompok ini, etnis Cina merupakan golongan terpenting karena ketrampilan, ketekunan, dan ketaatan pada penguasa VOC dibanding etnis-etnis lain (Haris, 1991). Sebagian besar etnis Cina berprofesi sebagai pedagang, selebihnya sebagai tukang sepatu, tukang cuci, tukang cat, tukang kayu, pembuat bata, pembuat arak, pembuat dan penjual gula, juru masak, pengusaha dan penyewa perahu, dan petani sayur (Milone, 1975).

Pada awalnya lokasi pemukiman etnis Cina terletak di dalam tembok kota tetapi setelah terjadi pemberontakan yang disusul oleh pembantaian terhadap kelompok etnis Cina maka penguasa Batavia melarang kelompok etnis tersebut menetap di dalam tembok kota. Lokasi pemukiman kelompok etnis Cina di dalam kota adalah di sepanjang Sungai Ciliwung, di sekitar Binnenhospitaal, dan sekitar Hoenderpasarbrug; sedang di luar tembk kota berlokasi di hampir seluruh bagian kota bagian depan.

Selain etnis Cina, etnis lain yang termasuk dalam kelompok penduduk kelas tiga ini adalah Moor. Sebutan orang Moor pada awalnya diperuntukkan bagi orang-orang Islam yang berasal dari Kalingga, India tetapi pada perkembangan selanjutnya sebutan ini ditujukan juga untuk orang-orang Islam yang berasal dari Gujarat, Benggala, Parsi dan Arab (Haris, 1991). Pada umumnya profesi yang dilakukan oleh orang Moor sebagai pedagang tekstil dan sebagian kecil sebagai serdadu. Lokasi pemukiman kelompok masyarakat ini pada awalnya terletak di kota bagian barat tetapi selanjutnya pemukiman tersebut berkembang ke sebelah barat kota terutama sekitar Utrechschepoort, sebelah utara Bacherachtgracht, dan sebelah selatan Amanusgracht.

Kelompok etnis lainyang termasuk dalam Kelompok Timur Asing adalah Jepang. Pada abad XVII-XVIII jumlah penduduk Batavia yang berasal dari etnis ini tidak diketahui secara tepat demikian juga mengenai profesi yang dilakukannya. Dalam peta-peta kuna juga tidak pernah tercantum lokasi pemukiman kelompok etnis Jepang sehingga kemungkinan karena jumlahnya yang sangat sedikit penguasa Batavia tidak menetapkan lokasi tertentu untuk pemukimannya.

Kelompok etnis yang juga termasuk sebagai warga kelas tiga ini adalah Papanger. Sebutan orang Papanger ditujukan pada orang-orang yang berasal dari laut Manila yang merupakan serdadu Spanyol (de Haan, 1922). Pada awalnya orang-orang Papanger merupakan tawanan perang kemudian setelah satu tahun bekerja pada VOC mereka dibebaskan dan berprofesi sebagai serdadu atau polisi keamanan kota. Sama seperti kelompok etnis Jepang, penguasa Batavia tidak menetapkan lokasi tertentu untuk pemukimannya.

Penduduk Batavia yang merupakan penduduk kelas keempat adalah Mardijker. Sebutan Mardijker ditujukan kepada orang-orang dari Koromandel, Arakan, Malabar, 
Srilangka, dan Melayu yang berprofesi sebagai budak. Penguasa Batavia menetapkan lokasi pemukiman kelompok ini terutama di sebelah timur kota bagian depan.

Kelompok terakhir yang menduduki kelas terendah adalah orang-orang pribumi. Pada umumnya mereka berasal dari wilayah-wilayah di nusantara, yaitu Jawa, Balai, Makasar, Bugis, Madura, Buton, Mandar, Banda, Flores, Bima, Sumbawa, dan Timor. Profesi yang mereka jalani sebagai serdadu dan budak. Untuk pemukiman, penguasa Batavia menetapkan kelompok ini harus bermukim di luar tembok kota.

Kelompok etnis Jawa bermukim di sekitar Utrechschepoort, Diestpoort, Kali Krukut, Jacatraseweg, dan sebelah utara kota bagian barat. Kelompok etnis Bali bermukim di sebelah selatan Molenvliet, sebelah barat Bacherachtgracht, dan dekat kastil. Kelompok etnis Banda bermukim di sekitar Poort Roterdam. Kelompok etnis Ambon bermukim di sebelah barat kastil dan sebelah utara Amanusgracht. Kelompok etnis Buton bermukim di sekitar Antjolschevaart. Kelompok etnis Mandar bermukim di sekitar Buitengracht sebelah barat kota bagian depan. Kelompok etnis Makasar bermukim di sebelah utara Amanusgracht. Kelompok etnis Melayu bermukim di sebelah timur kota bagian depan. Untuk kelompok-kelompok etnis yang lain kemungkinan karena jumlahnya yang sedikit oleh penguasa Batavia secara administratif digabungkan dengan kelompok etnis yang jumlahnya lebih besar dan lokasi pemukimannya juga disatukan dengan kelompok etnis yang jumlahnya lebih besar tersebut.

Berdasarkan pengalaman Willey dalam penelitian di Viru Valley, Bruce G. Trigger memperingatkan bahwa faktor determinan yang menentukan setiap kelompok orang memilih pemukiman bukan sekedar faktor efesiensi dalam mobilitas. Lebih dari itu, faktor lingkungan, keterampilan dan teknologi tidak bisa diabaikan (Chang, 1968). Konsep ini sangat fleksibel mendasari kajian kota ortogenetik, dan bahkan juga bagi kota-kota heterogenetik.

Hal ini dapat dilihat di Kota Batavia pada abad XVII-XVIII dimana posisi kelompok etnis tertentu dalam struktur organisasi fisik kota menunjukkan kelas sosial yang tertinggi diberi kebebasan oleh pihak penguasa dalam menentukan lokasi pemukiman. Selain itu dalam penempatan kelompok etnis tersebut terlihat juga kedekatan kelompok etnis tertentu dengan pihak penguasa dimana kelompok etnis tersebut menguasai hampir seluruh sektor perekonomian kota.

Berdasarkan uraian di atas kelihatannya ada tiga akar segregasi ruang di kota Batavia abad XVII-XVIII Masehi. Pertama, ras dan agama. Ada kecenderungan bahwa setiap ras stereotipe dengan profesi tertentu, dimana mereka bermukim dalam satu lingkungan yang dipelihara berdasarkan azas primordialisme. Kedua, efesiensi dalam mobilitas. Sebagai kota moderen masyarakat kota Batavia juga sudah memperlihatkan 
konsep-konsep efesiensi, yakni pemukiman dekat dengan ruang pekerjaan. Ketiga, administrasi dan keamanan. Pengelompokan etnis yang terbentuk di Batavia juga cenderung dipengaruhi oleh pertimbangan administrasi yang dimonopoli oleh VOC. Kelompok-kelompok yang mempunyai hubungan langsung dengan VOC di bidang perdagangan ditempatkan tidak jauh dari kawasan niaga. Pertimbangan kedua adalah faktor keamanan, yakni kekhawatiran terhadap serangan-serangan kerajaan Islam pantai utara Pulau Jawa. Ketakutan itu ditambah lagi pengalaman pemberontakan Cina 1774 sehingga kelompok-kelompok etnis yang dianggap berpotensi untuk menimbulkan kekacauan ditempatkan di luar tembok kota.

\section{Kelompok Pinggiran}

Lingkungan buatan sebagai sebuah upaya pengorganisasian sosial mencerminkan dan merupakan cara untuk mengendalikan interaksi: keadaannya, intensitasnya, tingkatnya, dan arahnya (Catanesse, 1986). Bentuk kota dan reaksi penduduk terhadapnya berlangsung dua arah: secara fisik dan psikologis. Dampak fisik terhadap umat manusia signifikan dari sudut mobilitas fungsional elemen-elemen kota. Sementara dampak psikologis agak sulit ditentukan (Catanesse, 1986).

Kelompok-kelompok etnis yang berada di pinggiran kota bukanlah kelompok pinggiran dalam pengertian politik dan sosial-ekonomi. Padahal justru pengelompokan yang terbentuk di Batavia lebih berakar pada kuatnya ikatan primordial. Dengan demikian, masyarakat pinggiran kota Batavia hanya bisa dimengerti dalam kerangka letak suatu kelompok masyarakat dalam skala geografis yang ada di pinggiran kota dan sangat tipis dalam pengertian pinggiran politik, spsial ekonomi. Dalam pengertian politik, sosial, dan ekonomi, pinggiran adalah "the lack or difficulty of access to a reasonable and stable income" (Hagen Koo, 1981).

Adanya pemukiman-pemukiman di daerah pinggiran bukan merupakan kelompok pinggiran yang muncul karena faktor pembangkangan politik atau keterbelakangan ekonomi, tetapi justru didorong oleh adanya kebebasan dari kelompok etnis tersebut untuk mengembangkan kegiatan perekonomian di daerah-daerah yang merupakan wilayah kekuasaan VOC. Secara politik kelompok tersebut tidak dapat disebut dengan kelompok pinggiran karena mereka diberi kebebasan oleh penguasa untuk dipimpin oleh seseorang dari kelompoknya sendiri. Mungkin pola kota yang terdiri dari kampung-kampung dengan penduduk homogen dan mempunyai hubungan sosial kuat berkaitan dengan nilai-nilai paternalistik dan nepotisme yang sarat mendarah daging. Dengan pola kampung-kampung mekanisme interaksi yang kurang diinginkan dapat dikurangi dan demi kepentingan mencapai tingkat keleluasaan pribadi yang dikehendaki (Catanesse, 1986). Hal ini memperlihatkan masih adanya pola-pola kehidupan desa dan usaha mempertahankan tradisi kebudayaan asal. 
Selain itu, semakin padatnya pemukiman di dalam kota mengakibatkan kota semakin pengap dan kotor. Hal ini mengakibatkan warga kota mengalihkan pemukiman ke wilayah pinggiran kota. Awalnya, wilayah-wilayah pinggiran tersebut hanya merupakan tempat peristirahatan saja yang ditandai oleh banyak didirikannya landhuis. Pada masa kemudian banyaknya bangsa Eropa yang pindah ke wilayah pinggiran membentuk kelompok-kelompok yang terus berkembang menjadi sebuah pemukiman.

\section{Penutup (Kesimpulan)}

Berdasarkan pernyataan-pernyataan yang telah diuraikan sebelumnya dapat ditarik kesimpulan bahwa pemukiman kelompok-kelompok etnis di Batavia ditentukan selain berhubungan lingkungan yang mendukung profesi, juga soal ras dan agama serta efektivitas dalam mobilitas. Seperti kelompok-kelompok etnis yang berprofesi sebagai pedagang ditempatkan atau bermukim di dekat kawasan niaga. Kelompok-kelompok yang berprofesi sebagai pegawai administrasi ditempatkan di wilayah pusat kota yang merupakan kawasan pusat pemerintahan, sedangkan kelompok-kelompok yang berprofesi di bidang pertanian dan perkebunan serta kelompok-kelompok yang dianggap berpotensi untuk menimbulkan ancaman keamanan ditempatkan di wilayah pinggiran kota.

Akan tetapi karena suatu ras dan agama umumnya merupakan stereotipe profesi tertentu, maka profesi dapat dianggap sebagai faktor signifikan. Dengan demikian, kota Batavia pada abad XVII-XVIII Masehi masih bisa dianggap berciri kota praindustri, dimana tata ruangnya lebih berkaitan dengan aspek-aspek non-fisik, misalnya: kepentingan politik, pekerjaan, agama, dan ras (struktur sosial).

Pemekaran kota Batavia ke wilayah-wilayah pinggiran terutama ke arah selatan lebih dikarenakan oleh faktor ekonomi dan kebutuhan akan lingkungan yang sehat. Adanya pemukiman di wilayah pinggiran kota sebenarnya merupakan pendukung perekonomian kota Batavia, yaitu sebagai produsen kebutuhan-kebutuhan pokok kota. Hal ini menunjukkan kontribusi yang cukup besar dari pemukiman-pemukiman di wilayah pinggiran terhadap dinamika perekonomian pusat kota. Dengan demikian dapat dikatakan warga kota yang menetap di pinggiran kota secara politis tidak dapat dikatakan sebagai kelompok pinggiran secara hirarkis dari pusat, meskipun pada dasarnya lokasi pemukiman mereka secara geografis terletak di wilayah batas kota. 


\section{KEPUSTAKAAN}

Abeyasakere, Susan, 1987. Jakarta A History. Singapore: Oxford University Press.

Bintarto, R, 1986. Urbanisasi dan Permasalahannya. Jakarta: Ghalia Indonesia, cetakan kedua.

Breuning, H.A, 1981. Het Voormalige Batavia; een Hollandse Stedestichting in de Tropen anno 1619. Utrecht.

Catanesse, Anthony J, 1986. Pengantar Perencanaan Kota. Jakarta: Erlangga.

Cobban, James L, 1976. "Geographic Notes On The First Two Centuries Of Djakarta" dalam Changing South East Asian Cities: Reading On Urbanization Edited by Y.M. Yeung and C.P. Lo. Singapore: Oxford University Press.

De Chiara, Joseph dan Lee E. Koppelman, 1978. Site Planning Standards. Mc. Graw-Hill Company.

Diessen, J.R. van, 1989. Jakarta/Batavia, Het Centrum van Het Nederlandsch Kolonialerijk in Azie en zijn Cultuurhistorische. De Bilt: Contecleer bv.

E. Shevky \& Wendell Bell, 1955. Social Area Analysis. California: Stanford University Press.

Evers, Hans-Dieters, 1985. Sosiologi Perkotaan: Urbanisasi dan Sengketa Tanah di Indonesia dan Malaysia. Jakarta: LP3ES.

Gill, R.G, 1994. Kota Sekeluarga. Batavia, A Family of Cities. Tidak diterbitkan.

Haan, F. de, 1922. Oud Batavia Jilid 1 dan 2. Bandoeng.

Haris, Tawalinuddin, 1991. Jakarta dari Kota Tradisional sampai Kota Kolonial. Kajian terhadap Perkembangan dan Perubahan Morpologis dan Masyarakat Kota Abad XVI sampai Abad XVIII. Tesis. Program Pasca Sarjana Universitas Gadjah Mada Yogyakarta.

Heuken, Adolf, 1989. Historical Sight of Jakarta. Jakarta: Cipta Loka Caraka, cetakan kedua. 
Ijzerman, J.W, 1917. "Over Belegering van het Fort Jacatra (22 December $1618-1$ February 1619)" dalam BKI 73, hlm. 558 - 639.

Koo Hagen, 1981. "Development and Change" Sage. London and Beverly Hill, Vol. 12: 55 - 76.

Milone, Pauline Dublin, 1975. Queen City of The East. The Methamorphosis of a Colonial Capila. Michigan.

Novita, Aryandini, 1995. Kota Batavia Abad XVII - XVIII. Tata Kota dan Perkembangannya. Jakarta: Skripsi Jurusan Arkeologi, Fakultas Sastra, Universitas Indonesia.

Onggodiputro, Aris K, 1989. Pengantar Sejarah Perencanaan Perkotaan. Sebuah Kumpulan Karangan. Bandung: Intermasa, terjemahantavia.

Rahardjo, Supratikno, 1991. Pertumbuhan dan Keruntuhan Kota-kota Prakolonial di Indonesia: Suatu Kajian Menurut Model Evolusi. Jakarta: Tesis Fakultas Pasca Sarjana Universitas Indonesia.

Rappaport, Amos, 1985. "Tentang Asal Usul Kebudayaan Pemukiman", dalam Pengantar Sejarah Perencanaan Perkotaan, Anthony J. Catanese, et.al. Bandung: Intermasa.

Sadadi, Daruruh, 1992. Kanal-kanal di Batavia Abad XVII-XVIII (Sebuah Pendahuluan). Jakarta: Skripsi Jurusan Arkeologi, Fakultas Sastra, Universitas Indonesia.

Soekmono, R. (et.al), 1993. Perkembangan Pemukiman Jakarta dari Masa Bercocok Tanam sampai Metropolitan. Laporan penelitian Kerjasama Pemda DKI Jakarta dan Pusat Penelitian Kemasyarakatan dan Budaya Lembaga Penelitian Universitas Indonesia 1992-1993. Tidak diterbitkan.

Surjomihardjo, Abdurrachman, 1977. Perkembangan Kota Jakarta. Jakarta: Dinas Museum dan Sejarah DKI Jakarta. 


\section{TABEL : KOMPOSISI PENDUDUK BATAVIA ABAD XVII - XVIII BERDASARKAN PROFESI DAN LOKASI PEMUKIMANNYA}

\begin{tabular}{|c|c|c|c|}
\hline NO & $\begin{array}{l}\text { Kelompok } \\
\text { Penduduk }\end{array}$ & Profesi & Lokasi Pemukiman \\
\hline 1. & \begin{tabular}{ll}
\multicolumn{2}{l}{ Eropa } \\
- & Belanda \\
- & Jerman \\
- & Inggris \\
- & Perancis \\
- & Portugis
\end{tabular} & $\begin{array}{l}\text { Pejabat VOC } \\
\text { Pegawai VOC } \\
\text { Serdadu } \\
\text { Pengusaha swasta } \\
\text { Pemuka agama }\end{array}$ & $\begin{array}{l}\text { Tijgergracht } \\
\text { Jonkergracht } \\
\text { Sepanjang tembok kota } \\
\text { Sekitar Poort Roterdam } \\
\text { Sekitar Nieuwpoort } \\
\text { Sekitar Utrechtschepoort } \\
\text { Tepi-tepi jalan menuju luar kota }\end{array}$ \\
\hline 2. & Mestizo & $\begin{array}{l}\text { Pegawai VOC } \\
\text { Serdadu } \\
\text { Pengusaha swasta }\end{array}$ & $\begin{array}{l}\text { Kota bagian Timur } \\
\text { Sebelah timur Kota bagian Depan }\end{array}$ \\
\hline 3. & $\begin{array}{l}\text { Timur Asing: } \\
\text { - } \quad \text { Cina } \\
\text { - } \quad \text { Moor } \\
\text { - } \quad \text { Jepang } \\
\text { - } \quad \text { Papanger }\end{array}$ & $\begin{array}{l}\text { Pedagang } \\
\text { Tukang sepatu } \\
\text { Tukang cuci } \\
\text { Tukang cat } \\
\text { Tukang kayu } \\
\text { Pembuat bata } \\
\text { Pembuat arak } \\
\text { Pembuat dan penjual gula } \\
\text { Juru masak } \\
\text { Pengusaha penyewaan kapal } \\
\text { Petani sayuran } \\
\text { Serdadu } \\
\text { Polisi keamanan kota }\end{array}$ & $\begin{array}{l}\text { Sepanjang S. Ciliwung } \\
\text { Sekitar Hoenderpasarbrug } \\
\text { Sekitar Binnenhospitaal } \\
\text { Kota bagian Depan } \\
\text { Kota bagian Barat } \\
\text { Sekitar Utrechtschepoort } \\
\text { Sekitar Bacherachtgracht } \\
\text { Sekitar Amanusgracht }\end{array}$ \\
\hline 4. & Mardijker & Budak & Sebelah timur Kota bagian depan \\
\hline 5. & \begin{tabular}{ll}
\multicolumn{2}{l}{ Pribumi: } \\
- & Jawa \\
- & Bali \\
- & Makasar \\
- & Bugis \\
- & Mandar \\
- & Madura \\
- & Buton \\
- & Banda \\
- & Flores \\
- & Bima \\
- & Sumbawa \\
- & Timor
\end{tabular} & $\begin{array}{l}\text { Serdau } \\
\text { Budak } \\
\text { Pedagang }\end{array}$ & $\begin{array}{l}\text { Sekitar Utrechtschepoort } \\
\text { Sekitar Diestpoort } \\
\text { Sekitar Kali Krukut } \\
\text { Sekitar Jacatraseweg } \\
\text { Sekitar Overwaterweg } \\
\text { Sebelah utara Kota bagian Barat } \\
\text { Sekitar Bacherachtgracht } \\
\text { Dekat kastil } \\
\text { Sekitar Poort Roterdam } \\
\text { Sekitar Amanusgracht } \\
\text { Sekitar Antjolschevaart } \\
\text { Sekitar Buitengracht sebelah Barat } \\
\text { Kota bagian Barat } \\
\text { Sebelah timur Kota bagian Depan }\end{array}$ \\
\hline
\end{tabular}




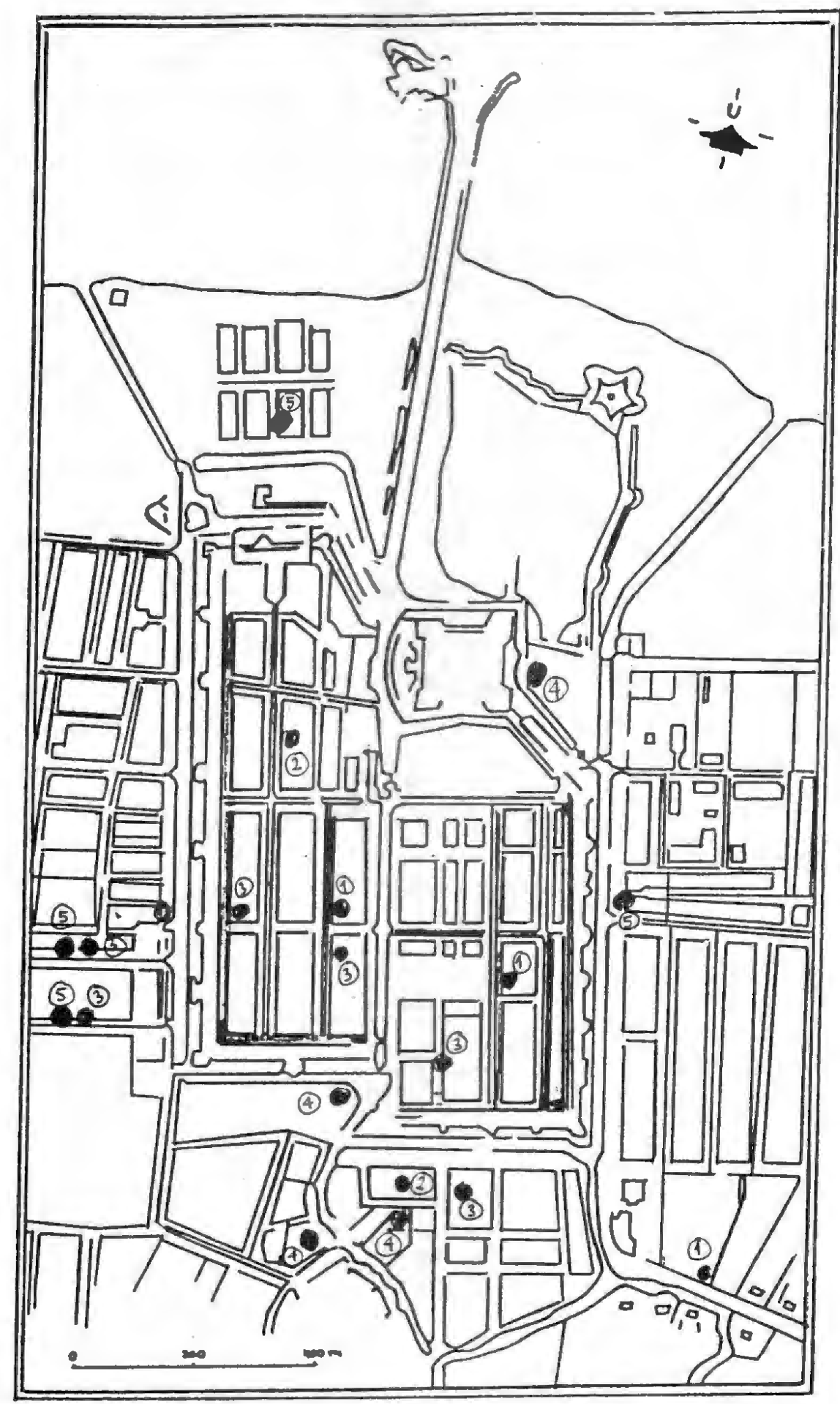

Peta 1. Peta Persebaran Penduduk di dalam tembok kota Batavia Abad XVII - XVIII

Berdasarkan kelompok Etnis 


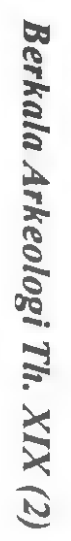

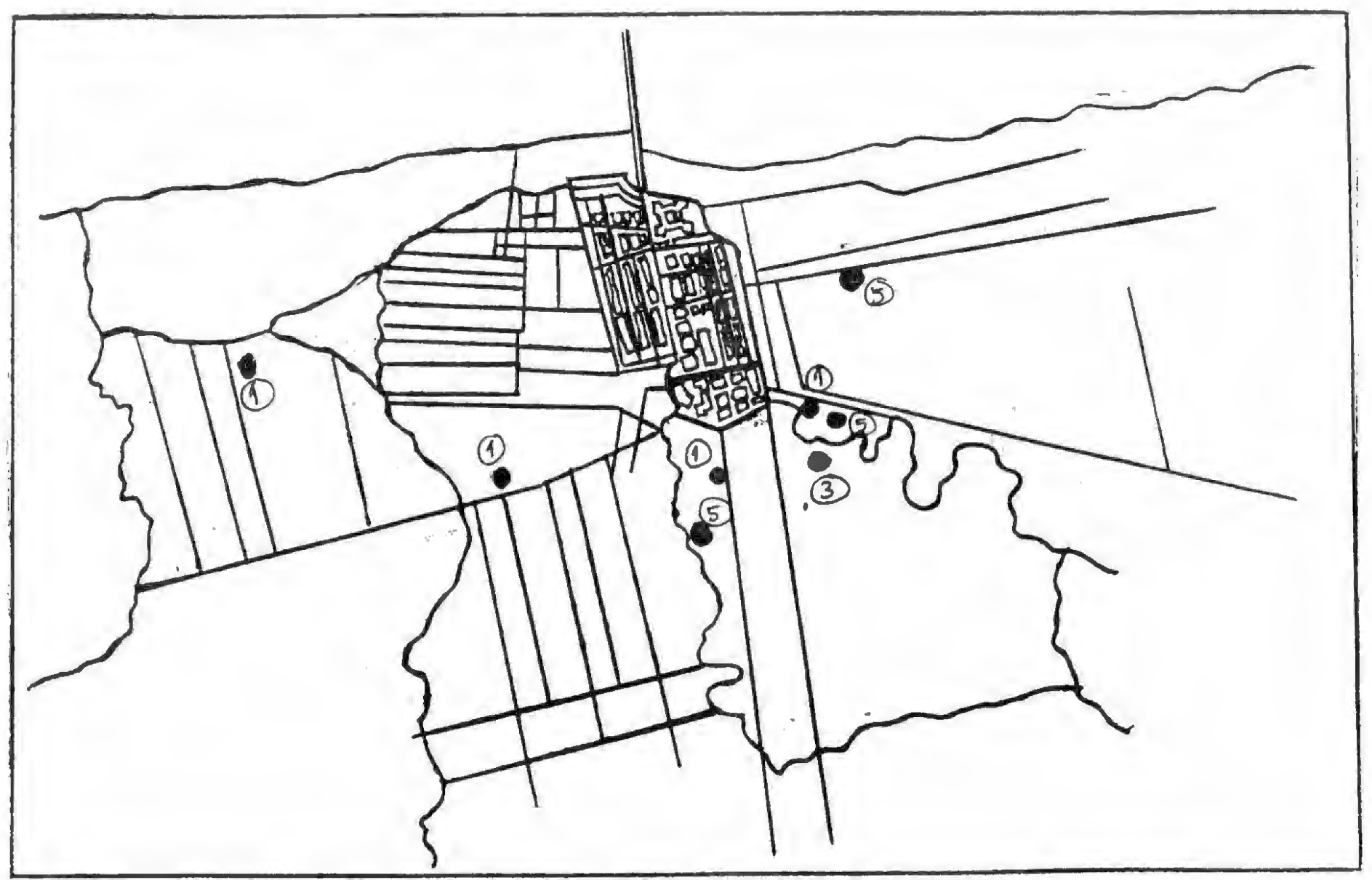

Peta 2. Peta Persebaran Penduduk di luar tembok kota Batavia Abad XVII - XVIII Berdasarkan kelompok Etnis 